\title{
UJI ANTIOKSIDAN DAN UJI BSLT PADA EKSTRAK KASAR Holothuria scabra DENGAN BERBAGAI PELARUT
}

\section{ANTIOXIDANT TEST AND BSLT TEST ON CRUDE EXTRACT Holothuria scabra WITH VARIOUS SOLVENTS}

\author{
Ardi Ardiansyah*, Abdullah Rasyid dan Aji Nugroho \\ Pusat Penelitian Oseanografi-LIPI, Jakarta, 14430, Indonesia \\ *E-mail: ardiardiansyah24@gmail.com
}

\begin{abstract}
Holothuria scabra is one of high-value sea cucumber. The beneficial aspect of sea cucumbers is determined by the source of raw materials. The extraction process is a process that happens before sea cucumbers are used. In this process, the use of a various solvent is not only to facilitate the production process but also to maintain the active material. Also, the amount of yield obtained in the extraction process becomes a consideration in the production process. One of the benefits that are often claimed is antioxidants. This study aims to determine the yield of sea cucumbers after the extraction process by maceration with various types of solvents then antioxidant testing was carried out with DPPH followed by BSLT test. It was commonly used and easy to do. Besides, BSLT test was carried out to determine the initial toxicity and potency to be developed as antibacterial, antifungal and anticancer candidates. Results showed that the highest yield was $8.98 \%$ produced by dry sea cucumber samples extracted with ethanol PA 70\% ethanol (code T5). In the results of the antioxidant tests, the best IC50 comes from dried sea cucumber extracted using ethyl acetate (code T2 and T3) with $1140 \pm 0.00$ ppm and1140 \pm 10 ppm respectively. In the BSLT test results, the lowest LC50 was shown by extract using $100 \%$ methanol PA solvent (T4 code), with 108 ppm.
\end{abstract}

Keywords: antioxidant, BSLT, Holothuria scabra, yield

\begin{abstract}
ABSTRAK
Teripang Holothuria scabra merupakan salah satu jenis teripang bernilai ekonomis tinggi. Manfaat yang diperoleh dari teripang sangat ditentukan oleh bentuk bahan baku yang digunakan. Proses ini biasanya merupakan proses lanjutan sebelum teripang dimanfaatkan. Pada proses ekstraksi penggunaan berbagai komposisi pelarut, selain bertujuan untuk mempermudah proses produksi juga dimaksudkan untuk mempertahankan material aktif. Selain itu, jumlah rendemen yang diperoleh pada proses ekstraksi menjadi pertimbangan selanjutnya dalam proses produksi. Salah satu manfaat yang sering diklaim pada produk teripang diantaranya kandungan antioksidan. Penelitian ini bertujuan untuk mengetahui rendemen teripang setelah dilakukan proses ekstrasi dengan metode maserasi dengan berbagai jenis pelarut kemudian dilakukan uji antioksidan dengan metode DPPH dilanjutkan dengan uji BSLT. Metode pengujian antioksidan DPPH dipilih karena umum digunakan dan mudah dilakukan. Selain itu, uji BSLT dilakukan untuk mengetahui toksisitas awal dan potensi untuk dikembangkan sebagai kandidat antibakteri, antijamur maupun antikanker. Hasil penelitian menunjukkan rendemen tertinggi yaitu 8,98\% yang diperoleh dari sampel kering hasil ekstraksi dengan pelarut etanol PA 70\% (kode T5). Pada hasil uji antoksidan yang dilakukan, besaran IC50 sampel terbaik adalah teripang kering yang diekstraksi menggunakan etil asetat (kode T2 and T3) dengan nilai yang hampir sama yaitu $1140 \pm 0,00 \mathrm{ppm}$ and $1140 \pm 10 \mathrm{ppm}$. Pada hasil uji BSLT, LC50 terendah ditunjukkan oleh ekstrak dengan pelarut metanol PA 100\% (kode T4), dengan nilai sebesar $108 \mathrm{ppm}$.
\end{abstract}

Kata kunci: antioksidan, BSLT, Holothuria scabra, rendemen 


\section{PENDAHULUAN}

Teripang merupakan salah satu komoditi ekspor sub sektor perikanan yang cukup potensial. Sebagai salah satu produk perikanan invertebrata yang populer, teripang dari kelas Holothuroidea telah lama dikonsumsi oleh orang Indonesia (Pankey, 2012). Penelitian tentang teripang yang pernah dilakukan di Indonesia telah menginventarisasi jenis-jenis teripang yang ada di beberapa wilayah perairan Indonesia misalnya di perairan Situbondo, Karimunjawa dan Ambon sudah dilakukan oleh Setyastuti and Purwati (2015) dan daerah lain di Indonesia juga sudah ditinjau keanekaragamannya oleh Setyastuti et al.,(2019) bahwa jenis teripang yang diteliti dan dikoleksi berjumlah empat puluh enam spesies.

Banyak dari spesies teripang yang memiliki nilai ekonomis tinggi berasal dari spesies Holothuria misalnya $H$. nobilis (black teatfish), H. fuscogilva (white teatfish), dan H. scabra (sandfish) sebagian besar terdistribusi di perairan tropis di Pasifik Barat dan Samudera Hindia (Ravinesh et al., 2014). Sebagian besar teripang dikeringkan terlebih dahulu sebelum dimanfaatkan. Teripang kering dijual secara komersial, terutama di pasar Asia dengan bisnis utama di Cina, diikuti oleh Korea, Indonesia, dan Jepang (Shiell, 2004). Menurut laporan statistik global Food and Agriculture Organization of United Nations (FAO) tahun 2004, Indonesia pernah tercatat menjadi produsen Teripang terbesar di dunia berdasarkan laporan global negara pengimpor utama, yaitu Hongkong dan Cina (Choo, 2008).

Sebagian besar spesies teripang kering yang dikomersialisasi merupakan bagian dari famili Aspidochirotids, genus Bohadschia, Holothuria, Actinopyga, Isostichopus, Stichopus, Parastichopus dan Thelenota (Stichopodidae) dan famili Dendrochirotids, genus Cucumaria (Purcell et al., 2012). Meskipun ada banyak spesies teripang yang dapat dibudidaya dan dipanen, tetapi hanya sekitar 20 spesies yang memiliki nilai ekonomis relatif tinggi, salah satunya $H$. scabra. Secara komersial, teripang kering dapat dikategorikan bernilai ekonomis rendah, sedang atau tinggi tergantung pada beberapa aspek seperti spesies, penampilan, kelimpahan, warna, bau, ketebalan dinding tubuh, tren pasar dan kebutuhan (Wen et al., 2010).

Pemanfaatan teripang di Indonesia sebagai bahan pangan dalam bentuk olahan dibanding produk perikanan lainnya tergolong rendah dan kurang populer, hal tersebut disebabkan teripang memiliki nilai estetika yang rendah dilihat dari bentuk fisik teripang yang terkesan menjijikkan (Karnila, 2011). Namun demikian, teripang memiliki kandungan nutrisi yang tinggi. Menurut Martoyo et al, (2006), kandungan nutrisi teripang dalam kondisi kering terdiri dari protein sebesar $82 \%$, lemak 1,7\%, kadar air 8,9\%, kadar abu 8,6\% dan kadar karbohidrat $4,8 \%$. Selain itu, kandungan terpenting dari teripang adalah kolagen, mineral, mukopolisakarida, glycosa-minoglycans, omega-3, 6, dan 9, asam amino, glukosamin dan kondroitin (Esmat et al., 2012).

Teripang $H$. scabra, mengandung sejumlah besar protein, khususnya kolagen, dan lipid sangat rendah. Selain itu, teripang ini memiliki kadar asam amino esensial, asam lemak esensial terutama asam nervonic dan asam arakidonat, yang juga mengandung Gamma Aminobutyric Acid (GABA), vitamin C, dan vitamin E (Sroyraya et al., 2017). Holothuroidea kaya akan kandungan bahan fungsional termasuk saponin, kondroitin sulfat, kolagen, asam amino, dan fenol. Bahan bioaktif ini potensial digunakan tidak hanya di industri makanan tetapi juga industri biomedis (Siahaan et al., 2017; Pengestuti and Arifin, 2017). Dari berbagai material aktif yang terkandung di dalam teripang, kandungan yang sering diklaim pada produk di pasaran diantaranya kandungan antioksidan. 
Antioksidan adalah zat yang dapat menghambat radikal bebas di dalam tubuh. Radikal bebas memainkan peran penting dalam tubuh manusia, seperti keterlibatan dalam energi diantaranya menciptakan proses, pertumbuhan sel, proses pensinyalan dan proses imunisasi (Lobo et al., 2010). Namun, aktivitas tinggi radikal bebas dapat menyebabkan berbagai gangguan sel dan jaringan yang pada akhirnya dapat menyebabkan kematian sel, kelainan gen dan kanker (Kulbacka et al., 2012). Senyawa yang berfungsi sebagai antioksidan yang terkandung dalam teripang diantaranya fenol, Vitamin C, vitamin E, dan terpen (Sroyraya et al., 2017; Nobsathian et al., 2017).

Pada penelitian ini, teripang $H$. scabra basah dan kering diekstrak dengan berbagai komposisi pelarut untuk menghasilkan ekstrak kasar. Pelarut yang digunakan bersifat polar dan semi polar. Penggunaan berbagai komposisi pelarut biasanya dipilih selain untuk mempermudah proses produksi juga dimaksudkan untuk mempertahankan material aktif yang dituju sebagai senyawa marker. Hasil ekstraksi tersebut dilakukan dengan uji antioksidan dengan metode DPPH untuk selanjutnya dilakukan juga uji BSLT. Uji BSLT dilakukan untuk mengetahui toksisitas tahap awal dan potensi untuk dikembangkan sebagai kandidat antibakteri, antijamur maupun antikanker.

\section{METODE PENELITIAN}

\subsection{Ekstraksi dengan Maserasi}

Teripang segar dikumpulkan dari lokasi sampling di daerah Lampung dan teripang kering yang dibeli dari nelayan di lokasi tersebut. Selanjutnya teripang tersebut dicacah untuk memperluas permukaanya dan kemudian diekstraksi menggunakan pelarut masing-masing sebanyak $180 \mathrm{~g}$ dengan metode maserasi. Pelarut yang digunakan adalah pelarut polar (metanol, etanol), dan pelarut semi polar (etil asetat) dengan konsentrasi tertentu. Proses maserasi dilakukan beberapa kali pengulangan sampai diperoleh filtrat yang bening. Setelah dilakukan penyaringan beberapa kali, filtrat yang diperoleh dipekatkan menggunakan rotary evaporator pada suhu $40^{\circ} \mathrm{C}$ dan dikeringkan dengan gas nitrogen.

Metode ekstraksi berupa maserasi dipilih karena pada proses tersebut tidak terjadi pemanasan seperti metode lain, seperti sokletasi. Sehingga diharapkan kandungan antioksidan yang terdapat pada larutan ekstrak tidak rusak, meskipun maserasi memiliki kelemahan yaitu pelarut yang digunakan akan lebih boros. Adapun penggunaan metanol tidak diperuntukan dalam proses pengolahan yang mengarah kepada produk konsumsi oral seperti klasifikasi yang ditetapkan oleh FDA (2017).

\subsection{Uji Antioksidan dengan Metode DPPH}

Ekstrak teripang dengan variasi konsentrasi berbeda yaitu rentang 0.1 mg. $\mathrm{mL}^{-1}$ hingga $2 \mathrm{mg} \cdot \mathrm{mL}^{-1}$ disiapkan untuk dianalisa. Sebanyak $160 \mu \mathrm{L}$ larutan ekstrak ditambahkan dengan $40 \mu \mathrm{L}$ larutan $1 \mathrm{mM}$ DPPH (Sigma, D9132) di dalam 96 well plates. Sampel diinkubasi selama 30 menit pada suhu ruang. Absorbansi diukur pada panjang gelombang $515 \mathrm{~nm}$ menggunakan Tecan $®$ Microplate Reader. BHT (Butylated hydrotoluene) (Sigma, W218405-1KG-K) dan Quercetin (Sigma, Q4951-10G) digunakan sebagai baku standar dengan kondisi yang sama. Konsentrasi yang digunakan yaitu $001 \mathrm{mg} \cdot \mathrm{mL}^{-1}$ hingga 0,005 mg. $\mathrm{mL}^{-1}$ untuk BHT dan $0,00025 \mathrm{mg} \cdot \mathrm{mL}^{-1}$ hingga $0,001 \mathrm{mg} \cdot \mathrm{mL}^{-1}$ untuk Quercetin. Pengukuran diulang 3 kali dan diambil rerata \pm standar errornya, kemudian aktivitas penghambatan dihitung. Aktivitas penghambatan radikal bebas dihitung menggunakan rumus:

$\%$ hambatan $=\left(\frac{1-A \text { sampel }}{A \text { control }}\right) \times 100 \%$ 


\subsection{Uji BSLT}

Sebanyak 10 naupili Artemia salina Leach dipipet ke dalam masing-masing botol vial yang telah berisi ekstrak dalam berbagai konsentrasi dan kontrol, kemudian ditambahkan air laut hingga volume $5 \mathrm{~mL}$. Selanjutnya botol vial ditutup dengan tutup karet dan dibiarkan selama 24 jam. Kematian pada setiap konsentrasi dicatat dan dibandingkan dengan kontrol. Pengukuran diulang 3 kali dan diambil rerata, lalu dihitung menggunakan rumus:

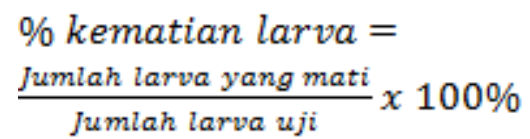

Dari masing-masing nilai kematian yang didapat selanjutnya diubah ke dalam nilai probit (probability unit) sebagai nilai mortalitas. Nilai probit didapatkan dengan mencocokan besaran persentase kematian dengan tabel probit. Begitu juga dengan nilai konsenterasi uji yang digunakan diubah ke dalam Log10. Nilai probit digunakan sebagai sumbu Y dan nilai Log sebagai sumbu X untuk membuat kurva standar dalam mencari nilai IC50. Setelah didapatkan hasil nilai

Tabel 1. Rendeman hasil maserasi.
IC50 selanjutnya besaran Log diubah kembali ke dalam nilai konsenterasi.

\section{HASIL DAN PEMBAHASAN}

\subsection{Hasil Ekstraksi Teripang}

Sesuai persyaratan SNI, teripang segar dan teripang kering yang digunakan adalah teripang yang tidak terkontaminasi, tidak ada tanda kerusakan dan pemalsuan, serta tidak ada risiko bagi kesehatan manusia (SNI, 2009). Oleh karena itu, teripang segar yang diperoleh langsung dikeluarkan isi perutnya kemudian dimasukkan ke dalam kontainer dingin untuk mencegah dari proses pembusukan. Sedangkan teripang kering yang diambil adalah teripang yang dipilih secara kasat mata, memiliki kadar air yang paling sedikit serta tidak nampak adanya jamur pada permukaan teripang tersebut.

Rendemen ekstrak yang diperoleh dengan pelarut polar dan semi polar ditunjukkan pada Tabel 1. Rendemen tertinggi diperoleh dari sampel teripang kering dengan pelarut etanol PA 70\% (kode T5) dengan rendemen sebesar 8,98\%. Sedangkan untuk sampel basah, rendemen paling banyak terdapat pada ekstrak dengan pelarut etanol PA 100\% (kode T9) dengan rendemen sebesar $2,57 \%$.

\begin{tabular}{|c|c|c|c|c|c|}
\hline No. & Jenis & Kode & Berat & Pelarut & $\begin{array}{c}\text { Rendemen } \\
(\%)\end{array}$ \\
\hline 1. & Teripang Kering & $\mathrm{T} 1$ & $180 \mathrm{~g}$ & $\mathrm{MeOH}-\mathrm{PA}-100 \%$ & 4,46 \\
\hline 2. & Teripang Kering & $\mathrm{T} 2$ & $180 \mathrm{~g}$ & $\mathrm{EtAc}-\mathrm{PA}-100 \%$ & 0,13 \\
\hline 3. & Teripang Kering & $\mathrm{T} 3$ & $180 \mathrm{~g}$ & EtAc - Teknis - $100 \%$ & 0,14 \\
\hline 4. & Teripang Kering & $\mathrm{T} 4$ & $180 \mathrm{~g}$ & $\mathrm{EtOH}-\mathrm{PA}-100 \%$ & 0,37 \\
\hline 5. & Teripang Kering & T5 & $180 \mathrm{~g}$ & $\mathrm{EtOH}-\mathrm{PA}-70 \%$ & 8,98 \\
\hline 6. & Teripang Basah & T6 & $180 \mathrm{~g}$ & $\mathrm{MeOH}-\mathrm{PA}-100 \%$ & 2,51 \\
\hline 7. & Teripang Basah & $\mathrm{T} 7$ & $180 \mathrm{~g}$ & EtAc $-\mathrm{PA}-100 \%$ & 0,001 \\
\hline 8. & Teripang Basah & $\mathrm{T} 8$ & $180 \mathrm{~g}$ & EtAc - Teknis - $100 \%$ & 0,014 \\
\hline 9. & Teripang Basah & T9 & $180 \mathrm{~g}$ & $\mathrm{EtOH}-\mathrm{PA}-100 \%$ & 2,57 \\
\hline 10. & Teripang Basah & $\mathrm{T} 10$ & $180 \mathrm{~g}$ & $\mathrm{EtOH}-\mathrm{PA}-70 \%$ & 1,065 \\
\hline
\end{tabular}

\subsection{Hasil Uji Antioksidan}

Berdasarkan hasil uji antoksidan, besaran IC50 sampel terbaik adalah teripang kering yang diekstraksi menggunakan etil asetat (kode T2\&T3), dengan nilai yang sama yaitu $1,14 \pm 0,00 \mathrm{mg} \mathrm{mL}-1,1,14 \pm 0,01 \mathrm{mg}$ 
mL-1. Adapun sampel T10 memiliki aktivitas antioksidan terendah dengan IC50 sebesar 18,54 $\pm 0,71 \mathrm{mg} \mathrm{mL}-1$. Sedangkan sampel T7 dan T8 tidak diujikan, karena rendemen yang didapat tidak mencukupi massa minimal untuk diujikan. Hasil uji ditunjukkan pada Tabel 2.

Teripang adalah salah satu organisme laut yang dapat dieksplorasi sebagai sumber potensial antioksidan. Pada penelitian ini, uji antioksidan dilakukan dengan metode DPPH. DPPH menghasilkan larutan violet dalam metanol dan intensitas warnanya akan berkurang ketika bereaksi dengan senyawa antioksidan. Perubahan warna digunakan untuk mengevaluasi aktivitas antioksidan dari ekstrak (Biswas et al., 2010; Garcia et al., 2012).

Pada uji antioksidan yang dilakukan, tercatat bahwa aktivitas penghambatan DPPH semakin meningkat dengan peningkatan konsentrasi baik untuk standar maupun ekstrak H. Scabra, dalam hal ini standar yang digunakan adalah BHT dan Quercetin. Berdasarkan nilai IC50, aktivitas antioksidan dapat digolongkan menjadi 5 (lima) golongan dari sangat kuat (IC50 $<50$ ppm), kuat (50 ppm<IC50>100 ppm), sedang (100 ppm<IC50>150 ppm), lemah (150 ppm<IC50> $200 \mathrm{ppm}$ ), dan sangat lemah (IC50>200 ppm) (Molyneux, 2004). Hasil penelitian menunjukkan bahwa hanya standar (BHT dan Quercetin) yang termasuk dalam kategori antioksidan sangat kuat. Adapun ekstrak yang diujikan masih tergolong sangat lemah, sama seperti hasil pada penelitian sebelumnya (Ardiansyah, A, 2016; Nobsathian et al., 2017) dengan standar yang digunakan berupa asam askorbat, teripang jenis $H$. scabra menunjukkan aktivitas antioksidan yang lebih rendah daripada standar. Hal ini dapat disebabkan oleh pengujian aktivitas antioksidan masih dilakukan terhadap ekstrak kasar. Jika dilakukan proses pemisahan lebih lanjut hingga didapatkan senyawa murni maka akan memiliki nilai aktivitas antioksidan yang lebih kuat dibanding ekstrak kasar seperti yang dilakukan oleh Nobsathian et al., 2017 dimana aktivitas antioksidan dan senyawa murni memiliki aktivitas lebih tinggi dari ekstrak kasar bahkan standar.

Tabel 2. Hasil uji antioksidan dengan Metode DPPH.

\begin{tabular}{|c|c|c|c|c|c|c|}
\hline No & Jenis & Kode & $\begin{array}{l}\text { Konsentrasi } \\
(\mathrm{mg} / \mathrm{ml})\end{array}$ & $\%$ Inhibisi & Persamaan Regresi & $\begin{array}{l}\text { IC50 } \\
(\mathrm{ppm})\end{array}$ \\
\hline 1 & $\begin{array}{l}\text { Teripang } \\
\text { Kering }\end{array}$ & T1 & $\begin{array}{c}2 \\
1 \\
0,5 \\
0,2 \\
0,1\end{array}$ & $\begin{array}{c}16,44 \pm 1,05 \\
8,70 \pm 0,37 \\
4,88 \pm 0,36 \\
2,92 \pm 0,35 \\
1,42 \pm 0,40\end{array}$ & $y=7.726 x+1.0001$ & $6340 \pm 380$ \\
\hline 2 & $\begin{array}{l}\text { Teripang } \\
\text { Kering }\end{array}$ & $\mathrm{T} 2$ & $\begin{array}{c}2 \\
1 \\
0,5 \\
0,2 \\
0,1\end{array}$ & $\begin{array}{c}76,21 \pm 0,34 \\
51,80 \pm 0,09 \\
30,56 \pm 0,26 \\
15,13 \pm 0,44 \\
8,94 \pm 0,51\end{array}$ & $y=35.081 x+9.8652$ & $1140 \pm 0.00$ \\
\hline 3 & $\begin{array}{l}\text { Teripang } \\
\text { Kering }\end{array}$ & $\mathrm{T} 3$ & $\begin{array}{c}2 \\
1 \\
0,5 \\
0,2 \\
0,1\end{array}$ & $\begin{array}{c}75,30 \pm 0,54 \\
52,69 \pm 0,28 \\
31,80 \pm 0,32 \\
15,73 \pm 0,33 \\
9,05 \pm 0,18\end{array}$ & $y=34,398 x+10,772$ & $1140 \pm 10$ \\
\hline
\end{tabular}




\begin{tabular}{|c|c|c|c|c|c|c|}
\hline No & Jenis & Kode & $\begin{array}{l}\text { Konsentrasi } \\
(\mathrm{mg} / \mathrm{ml})\end{array}$ & $\%$ Inhibisi & Persamaan Regresi & $\begin{array}{l}\text { IC50 } \\
(\mathrm{ppm})\end{array}$ \\
\hline \multirow[t]{5}{*}{4} & Teripang & $\mathrm{T} 4$ & 2 & $36,43 \pm 0,12$ & & \\
\hline & Kering & & 1 & $21,21 \pm 0,13$ & $y=17,302 x+2.5406$ & $2740 \pm 30$ \\
\hline & & & 0,5 & $11,50 \pm 0,31$ & & \\
\hline & & & 0,2 & $6,09 \pm 0,21$ & & \\
\hline & & & 0,1 & $3,22 \pm 0,75$ & & \\
\hline \multirow[t]{5}{*}{5} & Teripang & T5 & 2 & $15,55 \pm 0,45$ & & \\
\hline & Kering & & 1 & $8,73 \pm 1,27$ & & \\
\hline & & & 0,5 & $6,00 \pm 0,66$ & $y=6,2363 x+2.8913$ & $7550 \pm 110$ \\
\hline & & & 0,2 & $4,09 \pm 0,15$ & & \\
\hline & & & 0,1 & $3,77 \pm 0,68$ & & \\
\hline \multirow[t]{5}{*}{6} & Teripang & T6 & 2 & $6,98 \pm 0,19$ & & \\
\hline & Basah & & 1 & $4,35 \pm 0,37$ & & \\
\hline & & & 0,5 & $2,59 \pm 0,47$ & $y=2.9558 x+1,18842$ & $16520 \pm 19$ \\
\hline & & & 0,2 & $2,36 \pm 0,21$ & & 30 \\
\hline & & & 0,1 & $0,87 \pm 1,29$ & & \\
\hline \multirow[t]{5}{*}{7} & Teripang & T9 & 2 & $10,11 \pm 0,46$ & & \\
\hline & Basah & & 1 & $6,19 \pm 0,79$ & & \\
\hline & & & 0,5 & $5,87 \pm 0,46$ & $y=3.1485 x+3.6417$ & $14720 \pm 13$ \\
\hline & & & 0,2 & $3,90 \pm 0,41$ & & 00 \\
\hline & & & 0,1 & $4,11 \pm 0,22$ & & \\
\hline \multirow[t]{5}{*}{8} & Teripang & $\mathrm{T} 10$ & 2 & $6,53 \pm 0,30$ & & \\
\hline & Basah & & 1 & $4,16 \pm 0,09$ & & \\
\hline & & & 0,5 & $2,63 \pm 0,26$ & $y=2,6245 x+1,3486$ & $18540 \pm 71$ \\
\hline & & & 0,2 & $1,64 \pm 0,20$ & & 0 \\
\hline & & & 0,1 & $1,76 \pm 0,32$ & & \\
\hline \multirow[t]{5}{*}{9} & & BHT & 0,05 & $70,33 \pm 0,54$ & & \\
\hline & & & 0,02 & $41,04 \pm 0,84$ & & \\
\hline & & & 0,01 & $26,36 \pm 0,66$ & $y=1267 x+9,8805$ & $30 \pm 0,00$ \\
\hline & & & 0,005 & $15,56 \pm 0,13$ & & \\
\hline & & & 0,001 & $5,07 \pm 0,84$ & & \\
\hline \multirow[t]{5}{*}{10} & & Quercetin & 0,01 & $74,26 \pm 0,98$ & & \\
\hline & & & 0,005 & $39,54 \pm 0,41$ & & \\
\hline & & & 0,001 & $8,80 \pm 0,78$ & $y=7331,5 x+1,5713$ & $10 \pm 0,00$ \\
\hline & & & 0,0005 & $5,23 \pm 1,70$ & & \\
\hline & & & 0,00025 & $2,84 \pm 0,07$ & & \\
\hline
\end{tabular}

Berdasarkan hasil yang diperoleh, teripang kering memiliki kandungan antioksidan yang lebih tinggi daripada teripang segar. Teripang kering jenis tertentu, terutama yang memiliki organ internal, memiliki aktivitas antioksidan yang lebih tinggi daripada teripang segar. Sifat antioksidan dari ekstrak alami umumnya berasal dari adanya beberapa bioproduk termasuk senyawa fenolik, kolagen, polifenol di bagian tubuh yang kandungannya berbeda antara teripang segar dan olahan (Zhong et al., 2007). Sumber fenolik teripang dimungkinkan berasal dari makanan teripang yang berupa fitoplankton dan partikel rumput laut yang kaya akan senyawa fenolik.

Senyawa fenolik telah terbukti berkorelasi dengan aktivitas antioksidan dari banyak ekstrak. Fenolik di dalam spesies teripang bertindak untuk mem-pertahankan 
sifat redoks. Pada tahun 2007, Mamelona et al. melaporkan kandungan fenolik yang lebih tinggi pada ekstrak air daripada yang terkandung dalam ekstrak etil asetat. Selain itu, Bordbar et al., 2011 juga menduga senyawa yang memiliki aktivitas sebagai antioksidan di teripang mayoritas adalah senyawa hidrofilik. Namun, hasil percobaan menunjukkan ekstrak dengan kepolaran lebih rendah memiliki aktivitas antioksidan yang lebih tinggi. Hal ini dimungkinkan dalam ekstrak tersebut kandungan zat yang memiliki sifat anti-oksidan tertinggi dapat berasal dari senyawa lain selain fenol. Akan tetapi, jenis zat antioksidan apa saja yang terdapat dalam ekstrak tidak diujikan lebih lanjut.

\subsection{Hasil Uji BSLT}

Uji BSLT dengan menggunakan telur udang (Artemia salina Leach) selain digunakan untuk mempelajari toksisitas sampel secara umum juga dapat digunakan untuk mengetahui potensi senyawa sebagai antikanker, antibakteri, dan antijamur (Mayer et al., 1982). Hasil uji BSLT dibuat berdasarkan hubungan antara Log C (konsentrasi) dengan nilai probit yang mewakili persen mortalitas hewan uji. Analisis probit merupakan analisis dengan tingkat kepercayaan 95\%, nilai probit didapatkan dari tabel probit.

Pada percobaan ini, nilai LC50 yang diperoleh menunjukkan angka bervariasi seperti yang terlihat pada Tabel 3. Nilai LC50 merupakan konsentrasi dimana zat menyebabkan kematian 50\% diperoleh dengan memakai persamaan linier. Nilai LC50 terendah ditunjukkan oleh ekstrak dengan pelarut etanol PA $100 \%$ (kode T4) dengan $108 \mathrm{ppm}$. Suatu ekstrak dikatakan aktif bila nilai LC50 < 1000 ppm (Fajarningsih et al., 2006) dan tergolong sangat aktif terhadap larva udang Artemia salina Leach jika menunjukkan nilai LC50 $\leq$ 30 ppm. National Cancer Institute (NCI) Amerika yang menyatakan standar efektifitas komponen bioaktif untuk melawan sel kanker adalah $\leq 30 \mu \mathrm{g} / \mathrm{mL}$ (Albuntana et al., 2011). Namun, pada percobaan ini tidak ditemukan nilai LC50 $\leq 30$ ppm. Dari hasil yang diperoleh menunjukkan bahwa semua ekstrak kasar kecuali ekstrak dengan pelarut etil asetat yang memiliki LC50<1000 ppm. Hal ini mengindikasikan kecenderungan bahwa semakin polar pelarut yang digunakan, aktivitas LC 50 semakin rendah.

Tabel 3. Hasil Uji BSLT ekstrak teripang berbagai jenis pelarut.

\begin{tabular}{|c|c|c|c|}
\hline No. & Jenis & Kode & $\begin{array}{l}\text { NilI LC50 } \\
(\mathrm{ppm})\end{array}$ \\
\hline 1 & $\begin{array}{c}\text { Teripang } \\
\text { Kering }\end{array}$ & $\mathrm{T} 1$ & 384,00 \\
\hline 2 & $\begin{array}{c}\text { Teripang } \\
\text { Kering }\end{array}$ & $\mathrm{T} 2$ & 38589,09 \\
\hline 3 & $\begin{array}{c}\text { Teripang } \\
\text { Kering }\end{array}$ & $\mathrm{T} 3$ & 2413,11 \\
\hline 4 & $\begin{array}{c}\text { Teripang } \\
\text { Kering }\end{array}$ & $\mathrm{T} 4$ & 233,23 \\
\hline 5 & $\begin{array}{c}\text { Teripang } \\
\text { Kering }\end{array}$ & T5 & 438,74 \\
\hline 6 & $\begin{array}{c}\text { Teripang } \\
\text { Basah }\end{array}$ & T6 & 108,00 \\
\hline 7 & $\begin{array}{c}\text { Teripang } \\
\text { Basah }\end{array}$ & $\mathrm{T} 7$ & - \\
\hline 8 & $\begin{array}{c}\text { Teripang } \\
\text { Basah }\end{array}$ & T8 & - \\
\hline 9 & $\begin{array}{c}\text { Teripang } \\
\text { Basah }\end{array}$ & T9 & 289,21 \\
\hline 10 & $\begin{array}{c}\text { Teripang } \\
\text { Basah }\end{array}$ & $\mathrm{T} 10$ & 278,28 \\
\hline
\end{tabular}

\section{KESIMPULAN}

Rendemen ekstrak tertinggi dihasilkan oleh sampel kering yang diekstraksi dengan pelarut etanol PA 70\% (kode T5) dengan hasil rendemen sebesar $8,98 \%$ sedangkan untuk sampel basah rendemen tertinggi terdapat pada ekstrak dengan pelarut etanol PA $100 \%$ (kode T9) dengan hasil rendemen sebesar $2,57 \%$. Pada hasil uji antioksidan yang dilakukan, besaran IC50 sampel terbaik adalah teripang kering 
yang diekstraksi menggunakan etil asetat (kode T2\&T3) dengan nilai yang hampir sama yaitu $1140 \pm 0,00$ ppm, $1140 \pm 10$ ppm. Namun, keduanya masih termasuk antioksidan kategori golongan sangat lemah. Pada hasil uji BSLT, LC50 terendah ditunjukkan oleh ekstrak dengan pelarut metanol PA 100\% (kode T4), dengan nilai sebesar 108 ppm. Pada penelitian ini teripang kering memiliki value yang lebih tinggi daripada teripang basah, hal tersebut ditunjukkan dari hasil rendemen ekstrak, hasil uji antioksidan dan hasil uji BSLT yang didapatkan.

\section{UCAPAN TERIMA KASIH}

Penulis mengucapkan terimakasih yang sebesar-besarnya kepada Kementerian Riset, Teknologi, dan Pendidikan Tinggi Republik Indonesia yang telah mendanai kegiatan penelitian ini sampai selesai melalui program Insinas.

\section{DAFTAR PUSTAKA}

Albuntana. A., Yasman, dan W. Wardhana. 2011. Uji toksisitas ekstrak empat jenis teripang suku Holothuriidae dari Kepulauan Penjaliran Timur, Kepulauan Seribu, Jakarta menggunakan brine shrimp lethality test (BSLT). J. Ilmu dan Teknologi Kelautan Tropis, 3(1): 65-72. https://doi.org/10.29244/jitkt.v3i1.783 5

Ardiansyah, A. 2016. Ekstraksi dan formulasi suspensi oral teripang Holothuria scabra sebagai sumber antioksidan. Oseanologi dan Limnologi di Indonesia, 1(1): 29-37. https://doi.org/10.14203/oldi.2016.v1i 1.42

Biswas, M., P.K. Haldar, and A.K. Ghosh. 2010. Antioxidant and free-radicalscavenging effects of fruits of Dregea volubilis. $J$. of Natural Science, Biology and Medicine, 1(1): 29-34. https://doi.org/10.4103/0976-

9668.71670

Bordbar, S., F. Anwar, and N. Saari. 2011. High-value components and bioactives from sea cucumbers for functional foods-a review. Mar. Drugs, 9(10): 1761-1805. https://doi.org/10.3390/md9101761

Choo. P.S. 2008. Population status, fisheries, and trade of sea cucumbers in Asia. In: V. Toral-Granda., A. Lovatelli, and M. Vasconcellos (ed.). Sea cucumbers: A global review of fisheries and trade. FAO Fisheries and Aquaculture Technical Paper. Rome. 81-118 pp.

Esmat, A.Y., M.M. Said, A.A. Soliman, K.S.H. El-Masry, and E.A. Badiea. 2012. The bioactive compound, antioxidant potential and hepatoprotective activity of sea cucumber (Holothuria atra) against thioacetamide intoxication in rats. Nutrion, 29(1): 258-267. https://doi.org/10.1016/j.nut.2012.06. 004

Fajarningsih, N.D., H.I. Januar, M. Nursid, dan T. Wikanta. 2006. Potensi antitumor ekstrak spons Crella papilata asal Taman Nasional Laut Kepulauan Seribu. J. Pascapanen dan Bioteknologi Kelautan dan Perikanan, 1(1): 35-41. http://dx.doi.org/10.15578/jpbkp.v1i1. 229

FDA. 2017. Q3C-Tables and list guidance for industry. U.S. Department of Health and Human Services Food and Drug Administration; Center for Drug Evaluation and Research (CDER). Center for Biologics Evaluation and Research (CBER).

https://www.fda.gov/regulatoryinformation/search-fda-guidancedocuments/q3c-tables-and-list-rev-3.

Garcia, E.J., T.L.C. Oldoni, S.M. de Alencar, A. Reis, A.D. Loguercio, and R.H.M. Grande. 2012. Antioxidant activity by 
DPPH assay of potential solutions to be applied on bleached teeth. Braz Dent J., 23(1): 22-27.

https://doi.org/10.1590/s010364402012000100004

Karnila, R. 2011. Pemanfaatan komponen bioaktif teripang dalam bidang kesehatan. Perpustakaan Univ. Riau, FAPERIKA UR.

Kulbacka, J., J. Saczko, A. Chwialkowska, A. Choromańska, and N. Skołucka. 2012. Apoptosis, free radicals and antioxidant defense in antitumor therapy. In: El-Missiry. (ed.). Antioxidant enzyme. http://doi.org/10.5772/50357

Lobo, V., A. Patil, A. Phatak, and N. Chandra. 2010. Free radicals, antioxidants and functional foods: Impact on human health. Pharmacognosy Reviews, 4(8): 118126.

http://doi.org/10.4103/09737847.70902

Mamelona, J., É. Pelletier, K. GirardLalancette, J. Legault, S. Karboune, and S. Kermasha. 2007. Quantification of phenolic contents and antioxidant capacity of Atlantic sea cucumber, Cucumaria frondosa. Food Chemistry, 104(3): 1040-1047. https://doi.org/10.1016/j.foodchem.20 07.01.016

Martoyo, J., N. Aji, dan T. Winanto. 2006. Budidaya teripang. Penebar Swadaya. Jakarta. 69 pp.

Molyneux, P. 2004. The use of stable free radical diphenylpicrylhydrazyl (DPPH) for estimating antioxidant. Songklanakarin J. of Science and Technology, 26(2): 211-219.

http://www.thaiscience.info/journals/ Article/SONG/10462423.pdf

Nobsathian, S., P. Tuchinda, P. Sobhon, Y. Tinikul, J. Poljaroen, R. Tinikul, M. Sroyraya, T. Poomton, and S. Chaichotranunt. 2017. An antioxidant activity of the whole body of
Holothuria scabra. Chemical and Biological Technologies in Agriculture, 4(4): 1-5. https://doi.org/10.1186/s40538-0170087-7

Pangestuti, R., T. Murniasih, M.Y. Putra, A. Rasyid, J.T. Wibowo, A. Ardiansyah, and F. Untari. 2016. Free radical scavenging activity of selected sea cucumber species from MataramLombok, Indonesia. J. Teknologi, 78(4-2): 179-185.

https://doi.org/10.11113/jt.v78.8202

Pangestuti, R. and Z. Arifin. 2018. Medicinal and health benefit effects of functional sea cucumbers. $J$. of Traditional and Complementary Medicine, 8(3): 341-351. https://doi.org/10.1016/j.jtcme.2017.0 6.007

Purcell, S.W., Y. Samyn, and C. Conand. 2012. Commercially important sea cucumbers of the world. FAO Species Catalogue for Fishery Purposes. Rome. 150 pp.

Ravinesh, R., F. Kim, V.C. Roveena, N.S. Milika, and C.S. Paul. 2014. Harvesting and processing of tropical sea cucumbers in Fiji. As. J. Food AgInd., 7(01): 035-046.

Setyastuti, A. and P. Purwati. 2015. Species list of Indonesian trepang. SPC Beche-de-mer Information Bulletin, 35: 19-25.

Setyastuti, A., I. Wirawati, S. Permadi, dan B. Vimono. 2019. Teripang Indonesia, jenis, sebaran, dan status nilai ekonomi. PT. Media Sains Nasional, Bogor. 75 pp.

Siahaan, E.A., R. Pangestuti, H. Munandar, and S.K. Kim. 2017. Cosmeceuticals properties of sea cucumbers: prospects and trends. Cosmetics, 5(3): 1-12.

https://doi.org/10.3390/cosmetics403 0026

Standar Nasional Indonesia (SNI). 2009. Standar Nasional Indonesia 2732.2- 
2009. Teripang kering-Bagian 2: Persyaratan Bahan Baku. Jakarta: Dewan Standarisasi Nasional.

Sroyraya, M., P.J. Hanna, T. Siangeham, B. Tinikul, P. Jatiujan, T. Poomtong, and P. Sobhon. 2017. Nutritional components of the sea cucumber Holothuria scabra. Functional Food in Health and Disease, 7(3): 168-181. https://ffhdj.com/index.php/ffhd/articl e/download/303/588

Wen, J., C. Hu, and S. Fan. 2010. Chemical composition and nutritional quality of sea cucumbers. J. Science of Food and Agriculture, 90(14): 2469-2474. https://doi.org/10.1002/jsfa.4108

Zhong, Y., M.A. Khan, and F. Shahidi. 2007. Compositional characteristics and antioxidant properties of fresh and processed sea cucumber (Cucumaria frondosa). J. Agriculture Food Chem, 55(4): 1188-1192.

http://dx.doi.org/10.1021/jf063085h

Received : 20 December 2018

Reviewed : 05 September 2019

Accepted : 25 December 2019 